\title{
Environmental License for Carbon Capture and Storage (CCS) Projects in Brazil
}

\author{
Hirdan Katarina de Medeiros Costa
}

IEE/ USP - Universidade de São Paulo, Brazil

Mariana Fernandes Miranda

IEE/ USP - Universidade de São Paulo, Brazil

Raíssa Moreira Lima Mendes Musarra

IEE/USP - Universidade de São Paulo, Brazil

Edmilson Moutinho dos Santos

IEE/ USP - Universidade de São Paulo, Brazil

Received: July 26, 2018 Accepted: August 15, 2018 Online published: August 22, 2018

doi:10.5296/jpag.v8i3.13430～URL: https://doi.org/10.5296/jpag.v8i3.13430

\begin{abstract}
This article presents the environmental licensing system in Brazil and its instrument, the environmental impact assessment (EIA) and its discussion on CCS activities. Globally, extractive industry development projects are well known to have environmental impacts, and Brazil is no exception. Since the adoption of the main Brazilian environmental laws, there has been a general perception that environmental licensing system and EIAs protects its environment. Besides the legal requirement for those tools, this article describes the specific rules on oil and gas projects (onshore and offshore). This research contributes as a review of Brazil's environmental legislation, including the specific oil and gas legislation, presented along with a comprehensive discussion of those tools. Finally, this paper essays a general contribution for an understanding environmental licensing for CCS activities. The research was done using the inductive method, based on the methodology of legal science and with bibliographic and normative research techniques, including institutional analysis.
\end{abstract}

Keywords: Environmental Policy; Carbon Capture and Storage; Brazilian Licensing System; 
CCS Brazilian Projects

\section{Introduction}

The appropriation of nature and of the different primary power sources by men, with the conversion of them into secondary power, as well as their availability to different final uses, led to environmental issues that nowadays society inherited and became responsible for controlling, mitigating and extinguishing (Costa et al., 2017).

From the primitive men to the contemporary, there is the record of significant increase in per capita energy consumption (Goldemberg, 2003). Oliveira et al. (2004, p. 41) point out that all the extraction, production, conversion, transformation, transportation and distribution steps, as well as the final use of energy, cause significant direct or indirect impacts on the environment. An example of direct impact are the oil leaks and the sea degradation; the indirect impacts are caused by pollution resulting from fossil fuel burning.

In order to avoid or at least minimize those impacts, several commitments and legislation were adopted and enacted by Brazilian institutions. It is important highlighting the launching of institutions that aim at making sure that the environmental protection will be assured. Thus, Brazil took part in the United Nations Conference on Human Environment in Stockholm (Sweden) in 1972. It was the first step to the creation of Brazilian institutions launched to ensure environmental protection. Accordingly, in 1973, the Special Environment Bureau (SEMA - Secretaria Especial do Meio Ambiente) was created as an agency linked to the Ministry of Inland. It was responsible for the political and managerial work in the environmental scope. Next, the 1981 National Environmental Policy Act was passed by Law 6,938/1981 and the 1988 Brazilian Federal Constitution (FC) assures the right to an ecologically balanced environment for present and future generations. The national Institute of Environment and of Renewable Natural Resource (IBAMA - Instituto Nacional do Meio Ambiente e dos Recursos Naturais Renováveis), a federal agency, was created in 1989 through Law 7,735 (IBAMA, 2017a); (Costa et al., 2017).

Considering the Brazilian institutional framework and legislation, this article intends to evaluate how the environmental licensing procedure for CCS activities could carry out by government agencies. Thus, we begin with an overview from Brazilian Federal Constitution, Brazilian Norms on Environmental Licensing and the description of the competent authority under Supplementary Law 140/2011. Finally, we analysis oil and gas projects to verify the analogous applicable law for CCS activities.

\section{Legal and Institutional Aspects of Environmental Licensing in Brazil}

\subsection{The 1998 Federal Constitution and the Environment}

The FC states the fundamental right to life (article 5). As it is prescribed in its $\S 2$ : "the rights and warranties expressed in the present Constitution do not exclude other rights and warranties that result from the regime and principles herein adopted". Thus, it brings the right for an ecologically balanced environment essential to a healthy quality of life, which is a reflex pathway at the elementary human right level (Cavalcante, Costa and Freitas, 2004) 
(Costa et al., 2017).

Article 225 of the FC assures the right to an ecologically balanced environment for present and future generations, and its $\S 3$ establishes that "conducts and activities deemed to be harmful to the environment shall subject the offender, either a natural or a legal person, to criminal and administrative penalties, regardless of the obligation to repair the damage [that is, civil liability]". Therefore, a sole incident may give rise to three different, parallel and independent liabilities upon the same person (Costa et al., 2017).

Important for this article is the constitutional duty of the Public Power to require environmental impact assessment (EIA), prior of the installation of works and activities which may potentially cause significant degradation of the environment (art. 225, § 1, IV).

Moraes (2010, p. 850-51) says that, in order to make it possible broadening the protection, the FC prescribed many rules, which are divisible in these big groups: assurance rules, each citizen is a legitimate part able to propose a public civil action; competence rules, it concerns the management competence common to the Federation, the State, the Federal District and the Municipalities; general rules, wherein the FC sparsely sets the rules related to environmental preservation (FC, articles. 170, VI; 173, §5; 174, § 3; 186, II; 200, VIII; 216, V; $231, \S 1)$.

Among those rules, the environmental licensing system will be examined in further detail.

\subsection{Environmental Licensing and the National Environmental Policy Act (NEPA)}

The 1981 National Environmental Policy Act, passed by Law 6,938 (NEPA - Política Nacional do Meio Ambiente), establishes the main formulation and application mechanisms of the environmental policy in Brazil. According to Milaré (2009, p. 325), this law was "a pioneer step in national public life, with regards to the dynamics of the environmental reality".

Article 2 of Law 6,938/1981 sets the principles of NEPA: "I - governmental action to keep the ecological balance, considering the environment as a public patrimony to be necessarily assured and protected, due to the collective use; II - rationalization of the use of the soil, the sub-soil, the water and the air; III - planning and supervising the use of environmental resources; IV - the protection of the ecosystems, and the preservation of representative areas; $\mathrm{V}$ - the control and zoning of potential or truly polluting activities; VI - incentives to studies and research on technologies oriented to the rational use and protection of environmental resources; VII - following up the environmental quality condition; VIII - recovering the degraded areas; IX - the protection of areas threatened by degradation; $\mathrm{X}$ - environmental education at all education levels, including community education, as a way to make it capable of participating in environment defense"(Brasil, 2017a).

According to Milaré (2009, p. 329), many of these principles are actually "action programs, methods or modalities". In fact, by checking on the content of items VI and X, the targets set to incentives directed to studies and research are highlighted, as well as the environmental education at all education levels. 
However, regardless of qualification, what matters is the enforcement of this rule, which is focused, above all, on the preservation, improvement and recovering of the environmental quality in order to ensure the right conditions to achieve socio-economic development, as well as on the national safety interests and on the protection of human life dignity.

Articles 4 and 5 of Law 6,938/1981 are also highlighted and they list the NEPA aims. The items in Article 4 focus on the balance topics between environmental development and preservation, the delimitation of action fields in each governmental sphere, the definition of environmental quality standards and the handling procedures of environmental resources, as well as on the imposition of the polluter pays principle (reparation), among other subjects.

Article 9 of Law 6938/1981 states the NEPA instruments and, among them, "assessing environmental impacts" and "licensing and revising the effective or potentially polluting activities".

The Public Power is responsible for the granting of licenses to those who are interested in developing effective and potentially polluting activities. Licenses are a "bounded and definite administrative act that implies the obligation of the Public Power to fulfill the claims of the interested person, after the correct legal requirements are exhaustively fulfilled" (Milaré, 2009, p. 419).

Even before the $1988 \mathrm{FC}$, environmental impact assessment was already a legally mandated instrument under the National Environmental Policy Law (article 9, III). At the outset, however, there was no express provision confirming the need for its realization prior to the development of activities that could cause changes in the environment. Decree $\mathrm{n}$. 88,351/1983 (Article 18, caput and paragraph 1), which was later revoked by Decree 99,274/1990 (article 17, caput and paragraph 1), brought the solution to the problem, making EIA, one of the species of the genus environmental impact assessment, a condition for the licensing of construction, installation, expansion and operation of establishments and activities capable of causing environmental degradation (MARCHESAN et al. 2011).

This last decree granted to the National Council of the Environment (CONAMA) the competence to regulate the environmental impact assessment. From this, came Resolution 001 of 1986. According to Marchesan et al. (2011), initially, and based on the concept of pollution brought by Law 6,938/1981, Resolution 001/1986 defined environmental impact as "any change in the physical, chemical and biological effects of the environment caused by any form of matter or energy resulting from human activities that directly or indirectly affect the health, safety and well-being of the population; social and economic activities; the biota; the aesthetic and sanitary conditions of the environment; the quality of environmental resources " (article 1).

Accordingly, the broader environmental licensing activity aims at issuing licenses to the performance of activities classified as environment change generators.

Thus, CONAMA Resolution 237/1997 defines environmental licensing as: "an administrative procedure through which the competent environmental agency grants licenses to the location, installation, enlargement and operation of ventures and activities that use environmental 
resources that, overall, may cause environmental degradation, by taking into account the legal and regulating dispositions, as well as the technical rules applied to the case" (CONAMA, 2017a).

Considering the environmental licensing concept, the juridical bound found in all the procedures is clearly noticeable, it covers the administrative, criminal and environmental rights. Law, as an autonomous discipline, plays a central role in the licensing focused on ensuring the adequacy of effective and potentially polluting procedures and activities based on regulatory precepts, including the technical ones, which concern other fields of the human knowledge.

Thus, it is worth considering the different connections among law, biology, ecology, engineering, economy, social sciences, etc. The environmental licensing involves a multi and interdisciplinary knowledge based on juridical principles set to assure the main Environmental Law aims, namely: an economic balanced environmental development. In this sense, the EIA is a key instrument.

According to Marchesan, Steingleder and Cappelli (2011), the EPIA (Environmental Prior Impact Assessment) is designed to prevent a project that is justifiable from the economic point of view or from the immediate interests of its proposer, has preventive nature, which makes it one of the most important instruments of environmental quality defense policy.

\subsection{The Distribution of Competences for Environmental Licensing}

Within the environmental sphere, the 1988 FC aimed at setting the duties of the Federation, States, Federal District, and municipalities. Accordingly, Milaré (2009, p. 190) refers to the collaborative federalism, since "most of the subject associated with environment protection may be disciplined, at once, by the Federation, States, Federal District and municipalities".

The administrative competences are common to all the entities. Article 23 of the FC refers to them, as follows: "It is a common competence of the Federation, States, Federal District and municipalities: (...) III - protecting the documents, the construction sites and other assets of historical, artistic and cultural value, the monuments, and remarkable natural landscapes and the archaeologic sites; (...) VI - protecting the environment and fighting against corruption in any of its forms; VII - preserving the forests, the fauna and the flora; VII - encouraging the livestock production and the food supply" (Brasil, 2017a).

Article 24 of the FC lists the legislative competences of the Federation, States and the Federal District: "It is the duty of the States and of the Federal District to legislate about: I Urbanistic (...) law; (...) VI - forests, hunting, fishing, fauna, nature conservation, soil and natural resources defense, environment protection and pollution control; VII - protection to the historical, cultural, artistic, touristic and landscape patrimony".

The municipalities have several private competences, among them, for instance, legislating about subjects of local interest, which may cover subjects of environmental concern, in addition to the state and federal legislation, which is predicted in Article 30, paragraph I.

Thus, in the scope of the current competence, the Federation sets general national interest 
rules (art. 24, $\S \S 1$ and 2), whereas the other entities promote the addition, through the focus on regional interests in the case of States and the Federal District, and on local interests in the municipal sphere.

With regards to the environmental licensing, Article 10 of Law 6,938/1981 established that: "the construction, installation, enlargement and functioning of establishments and activities that use environmental resources effectively or potentially polluting or able, under any circumstances, to cause environmental degradation will depend on previous environmental licensing." Thus, it will be competence of "IBAMA to propose to CONAMA the rules and standards to implement, follow and supervise the licensing exposed in the previous article, besides those resulting from CONAMA itself" (art. 11) (Brasil, 2017b).

The Supplementary Law 140/2011 was enacted to rule the common competence to the Federation, States, Federal District and the municipalities in their administrative actions (Brasil, 2017c).

Article 7 from Law 140/2011 states that the Federation must act to promote the environmental licensing of ventures and activities: a) located or developed in partnership in Brazil and in neighbor countries; b) located and developed in the sea shore, in the continental platform or in the exclusive economic zone; c) located or developed in indigenous lands; d) located or developed in conservation units set by the Federation, except for Environmental Protection Areas (APAs - Áreas de Proteção Ambiental); e) located or developed in 2 or more States; f) of military character, except for the environmental licensing in the terms of acts of the Executive Power, those that are predicted in the preparation and employment of the Military Forces; g) oriented to search, reproof, produce, benefit, transport, store and dispose radioactive material, in any stage, or that use nuclear energy; or h) that meet the typology set through the act of Executive Power and from the proposition of the National Tripartite Commission, which is assured by the participation of a CONAMA member and by the consideration of action criteria, polluting potential and the nature of the activity or of the venture (Brasil, 2017b).

Also, Article 8 approaches the administrative actions in the scope of the States to promote the environmental licensing of activities and ventures that use effectively or potentially polluting environmental resources, or those able, under any circumstance, to cause environment degradation, except the federal and municipal competences (paragraph XIV); as well as to promote the environmental licensing of activities or ventures located or developed in conservation units set by the Federation, except for the APAs.

Article 9 concerns the municipal competences to promote the environmental licensing of activities or ventures: a) that cause or may cause local environmental impacts, according to the typology defined by the respective Environmental State Councils by taking into consideration the action criteria, the potential polluter and the nature of the activity; or $b$ ) located in conservation units set by the municipalities, except for APAs. The municipalities must observe the attributions of the other federation entities during the performance of such activities. Due to the institutional features of the Federal District, its administrative competence concerning the environment cover the State and municipal attributions (art. 10). 
The Supplementary Law 140 also states that the licensing will be issued by a single federative entity (art. 13). The renovation must be required at least 120 days before the expiration of its validity, and it will be extended up to the definite statement of the competent environmental agency ( $\S 4$ of art. 14). The other interested federative entities may show themselves in a non-bounding manner (art. 13).

The environmental agencies must observe the deadlines and the extension of the licensing expiration dates, without the issuing of the environmental license, it does not imply a tacit issuing, but it sets the supplementary competence (art.14). Article 15 discusses the supplementary competence, according to the following terms: "The federative entities act under supplementary character in the administrative action and in the environmental authorization, in the following hypotheses: I - lack of capable environmental agencies or of environment councils in the State or in the Federal District, the Federation must take state and district administrative actions up to their creation; II - lack of capable environmental agency or environment council in the municipality, the State must take municipal administrative actions up to their creation; and III - lack of capable environmental agency or environmental council in the State and in the municipality, the Federation must take administrative actions up to their creation in one of the federative entities." (Brasil, 2017c). It is noticeable in the text of Article 15 that the competences listed in Articles 8 and 9 will be temporarily called by the Federation, through the respect of state, district and municipal attributions by the time the respective capable environmental agencies are created.

Moreover, particularly important for hydrocarbons projects is the Federal Decree 8,437/2015 (Brasil, 2017e) that establishes the IBAMA competence for the environmental licensing of "exploration and production of oil, natural gas and other fluid hydrocarbons in the following cases: (A) exploration and evaluation of reservoirs, including seismic acquisition activities, collection of bottom data (piston core), well drilling and long-term testing when performed in the marine environment and in the offshore transition zone; (B) production, including well drilling activities, production systems and drainage systems, when carried out in the marine environment (offshore) and in the offshore transition zone; and (C) production, when concerning unconventional oil and natural gas resources, in marine environment and in transboundary zone offshore or onshore, including well drilling, hydraulic fracturing and deployment Production and disposal systems.

\section{Environmental Impact Assessment (EIA) and Environmental Licensing}

As a rule, the environmental permitting procedure of oil and gas activities begins with the development of an Environmental Impact Assessment and the related report ("EIA/RIMA"), which must be submitted to the environmental agency with the application for the Previous Permit, as detailed bellow. Before entering further the EIA (and other environmental assessments), it is worth describing the environmental licensing procedure in Brazil.

\subsection{Environmental Licensing: General Aspects}

As it was highlighted in the environmental licensing definition found in CONAMA Resolution 237/1997, the environmental licensing is composed of stages. The licensing stages 
are described in CONAMA Resolution 237/1997, in its Article 10: (i) defining documents, environmental projects and assessments necessary to the beginning of the process; (ii) requirement of the environmental license by the entrepreneur, by making it public; (iii) the analysis done by the competent environmental agency of the presented documents, projects and environmental assessments [usually, EIA] and the performance of technical checks, whenever necessary; (iv) requirement of clarifications and of supplementations by the competent environmental agency resulting from public hearings; (vii) issuing conclusive technical opinion and, whenever necessary, juridical opinion; and (viii) deferment or rejection of the licensing request, giving it the proper publication.

So, the EIA is among the first steps to obtain the first of the environmental licenses to oil and gas projects activities.

Moreover, usually, the environmental licensing procedure encompasses three phases: (i) Previous License ("Licença Prévia - LP"): granted in the preliminary stage of the activity, approving its location and conception, certifying its environmental feasibility, and establishing basic requirements and conditions to be met in the next stages of its implementation; (ii) Installation License ("Licença de Instalação - LI"): which authorizes the installation of the activity in accordance with the specifications contained in the approved plans, programs and projects, including environmental control measures and other conditions; and (iii) Operation License ("Licença de Operação - LO"): which allows the operation of the activity subsequently to the verification of the effective compliance with the requirements set forth in the previously mentioned permits.

As a rule, for onshore activities these licenses are granted by the state environmental agency and for offshore activities by the federal agency, IBAMA. In cases involving activities which may cause significant national or regional environmental impacts, IBAMA has the authority to issue the permits. These activities include, among others: (i) those located or developed (i.a) in Brazil and in a bordering country; (i.b) within the territorial sea; (i.c) within the continental shelf; (i.d) within the limits of Indian lands; or (i.e) within federal conservation units; (ii) those located or developed in two or more States; and (iii) which direct environmental impacts go beyond the territorial borders of the Country or of one or more States.

It should be highlighted that, in cases of activities that affect coastal zones, a conflict of interests between state and federal agencies may be raised. This is because, according to the Brazilian Constitution (article 20, VII), coastal zones are in the domain of the Federal Government. As a rule, this fact does not necessarily mean that the federal agency should have the authority to grant environmental licenses, given that the environmental impact may not be significant and of national or regional proportions.

In any event, even though IBAMA is not necessarily empowered to grant environmental licenses in those cases, it can - and, in theory, it should - provide its opinion about the activity to be implemented in coastal zones or other areas of federal domain. In these cases, such participation must be guaranteed by the licensing agency.

Similarly, any agency (federal, state or municipal) that has interest in the implementation of 
certain activity has the right - and the duty - to participate in the environmental licensing procedure. In this fashion, within the environmental licensing procedure, the relevant licensing agency shall consider the technical expertise of other interested agencies, responsible for specific matters, such as forests, fauna, water, caves, health, culture (historic and cultural heritage), indigenous, traffic, infrastructure, among others.

Therefore, for example, if an activity may cause impacts in specific protected areas, the agency (federal, state or municipal) in charge of the management and control of these areas should, as a rule, participate in the environmental licensing procedure, by providing its technical opinion or, depending on the case, even granting its approval. Frequently, the environmental licenses (LP, LI and LO) establish, as conditions of validity, obligations to obtain certain approvals from other agencies (such as water use right permits, authorizations for intervention in permanent preservation areas or suppression of vegetation, approvals from agencies responsible for the management of conservation units, among others).

The EIA is the main assessment for a project and should evaluate and point out all the environmental and social impacts of the project, including those impacts on the specific matters described above.

\subsection{Environmental Assessments}

As for the term in paragraph III of Article 1 of CONAMA Resolution 237, environmental studies "are all and any studies associated with environmental aspects related to the location, installation, operation and enlargement of an activity or venture". The environment studies will reinforce the subsidies to analyze the required license. The EIA is the most common and complete of the environmental assessments, but other simpler assessments (EIR and SES) can be performed in some cases. The EIA, EIR and SES will be discussed in the following sub-items.

\subsubsection{Environmental Impact Assessment (EIA)}

EIA, as it was seen, is described in item IV of the first paragraph of Article 225 of the FC, which gives the Public Power the responsibility of "demanding, in the form of law, an environmental impact study before the installation of a construction site or activity that might potentially cause significant environmental degradation; such study will be properly made public."

EIA is one of the most "remarkable instruments to match the socio-economic development through the preservation of the environment quality, since it must be elaborated before the installation of the construction site or of the activity that might be the potential cause of significant degradation.” (Milaré 2009, p. 382).

The CONAMA Resolution 237/1997 repeats the constitutional statement in its Article 3, which describes in its single paragraph that, if the activity or venture is not potentially causing significant environmental degradation, the competent environmental agency may define the environment studies associated with the respective licensing process (Costa et al. 2017). 
EIA consists of the review of the scientific and legal literature about the subject, field works, laboratory analyses and the writing of the Environment Impact Report (EIR) (Machado, 2009). Accordingly, Article 11 of CONAMA resolution 237/1997 states that "the studies necessary to the licensing process must be done by legally expert professionals, afforded by the entrepreneur", through the content of its single paragraph, the administrative, civil and criminal responsibility of the entrepreneur and of these professionals.

In order to fulfill the goals stablished in the constitutional provision, Milare (2009) states that the EIA demands transparence and administrative motivation, since it must consider all the environmental effects of the project under analysis, as well as it must have a written fundament about the decisions made by the environmental agency; yet, it is necessary to be participative by invoking the community to give its opinion and to supervise the licensing procedure.

The Article 5 of CONAMA Resolution 001/1986 draws EIA guidelines:

I - Contemplating all the technological alternatives and the location of projects, by confronting them with the hypothesis of not putting the project in practice; Systematically identifying and avoiding the environmental impacts generated in the implementation and operation phases; III - Defining the limits of the geographic area about to be directly or indirectly affected by the impacts, which is called project influence area, by considering, in all cases, the hydrographic basin in which is it located; IV - Considering the governmental plans and programs proposed and under implementation in the project influence area, and its compatibility (CONAMA, 2017a).

The Article 6 of CONAMA Resolution 001/1986 sets the minimal content of EIA, namely: (i) the environmental diagnosis of the project influence area, in a way to feature the environmental situation in the area before the project implementation; (ii) environmental impact analysis of the project and of its alternatives through the identification, prediction of magnitude and the interpretation of the importance of relevant impacts; (iii) defining the mitigating measures of negative impacts; and (iv) elaborating the follow-up program and the monitoring of positive and negative impacts.

CONAMA Resolution 01/86 requires that EIA must be conducted by developers for new projects or expansions of projects listed in Article 2, including fossil fuel extraction, mining activities, ports, pipelines, transmission lines above $230 \mathrm{kV}$, energy power plants above 10 MW, etc. However, this list is only indicative and the environmental agencies may require EIA for other activities that may cause significant environmental degradation.

A duly documented EIA/RIMA must be made available to the public for comments. For this purpose, a Public Hearing is legally guaranteed and often held. Indeed, once called for by the environmental permitting agency, the Public Attorney, any civil association, or at least 50 persons, a Public Hearing must be held, being a condition for the validity of the license. During the Public Hearing, the public has the opportunity to ask for clarifications, to criticize the project, to request the adoption of certain measures, etc. 


\section{Macrothink}

Journal of Public Administration and Governance

ISSN 2161-7104

2018, Vol. 8, No. 3

The environmental agency must use the information provided during the Public Hearing to weigh the pros and cons of the project, but its decision is not bounded thereto.

The Previous License is issued with several conditions, the compliance with which is crucial for the granting of the Installation License, which also establishes conditions of validity, the compliance with which is fundamental for the granting of the Operation License. The issuance of both the Installation and Operation Licenses is often conditioned to specific approvals from other agencies (please refer to item 1 above). This overlap of authority between different agencies commonly results in conflicts of interests and delays in the implementation and operation of the activities. An overview from these explanations may be seen at Figure 1 (Key stages of the EIA process on Federal competence).

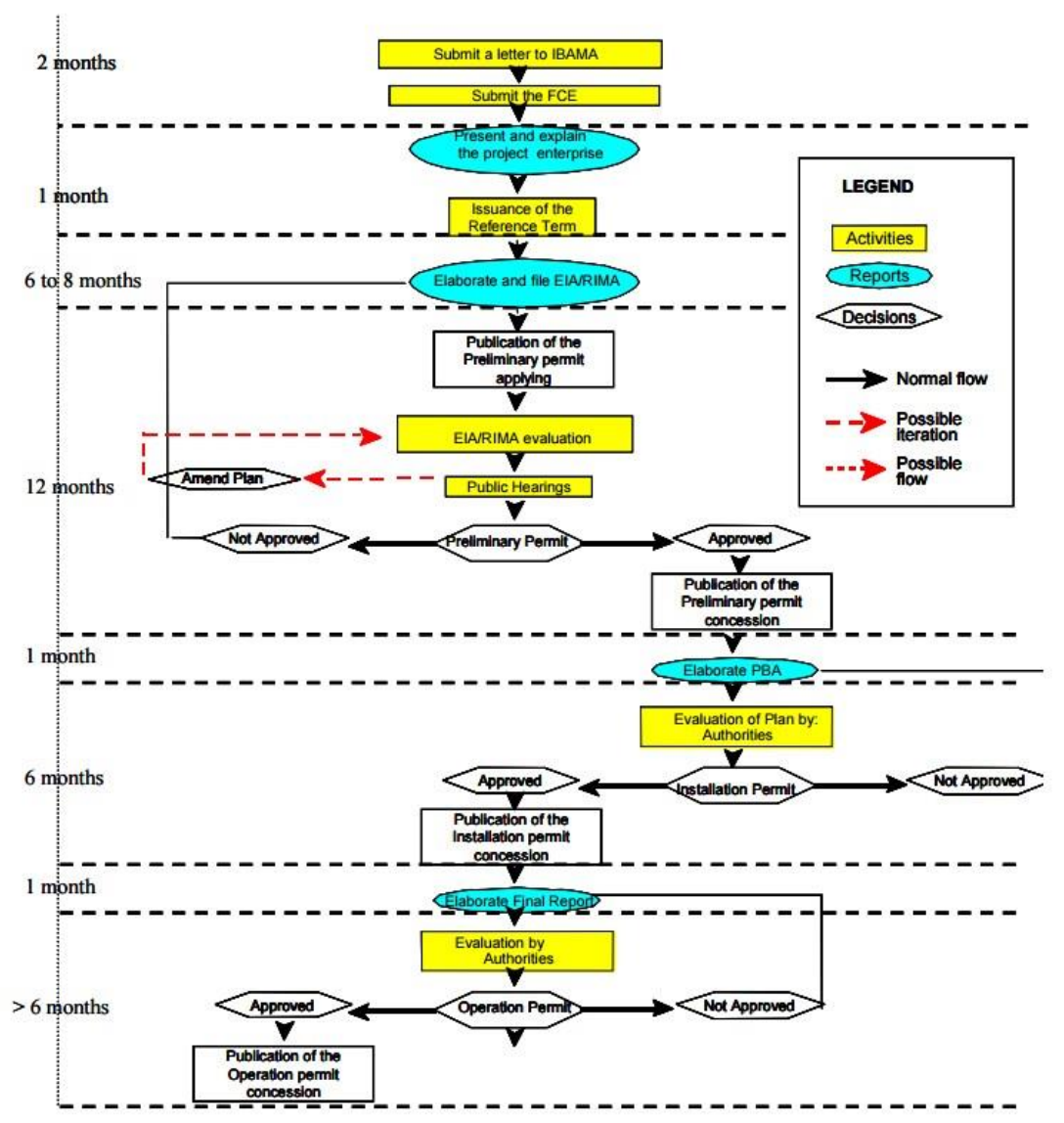

Figure 1. Key stages of the EIA process on Federal competence.

Source: The Environmental Impact Assessment Executive Summary of Eldorado Project, Brazil April, 2012.

\subsubsection{Environmental Impact Reports (EIR)}

EIR concerns the clarification of environmental advantages and effects of the project and it will reflect the EIA conclusions (Milaré, 2009). It must also be accessibly and comprehensibly written by different public types (single paragraph of Article 9 of CONAMA Resolution 001/1986) (CONAMA, 2017b). 


\section{MInstitute ${ }_{\text {Mnk }}^{\text {Macrothink }}$}

The Article 9 of CONAMA Resolution 001/1986 discusses the minimum EIR content and must describe:

I - The aims of and justifications to the project, its relation and match with the sectorial policies, plans and governmental programs; II - The description of the project and its technological and location alternatives, specific for each of them, in the construction and operation phases of the influence area, the raw material and man-power, the possible effluents, emissions, energy residues, the direct and indirect employment to be generated; III - The synthesis of results from studies about the environmental diagnoses of the project influence area; IV - the description of the probable environmental impacts of the implementation and operation of the activities by considering the project, its alternatives, the time horizon of impact incidence, and by indicating the methods, techniques and criteria adopted for its identification, quantification and interpretation; V - The featuring of the future environment quality of the influence area by comparing the different situations of project adoption and its alternatives, as well as the hypothesis of its non-execution; VI - The description of the effect expected from the mitigating measures associated with the negative impacts by mentioning those that could not be avoided, and the degree of expected changes; VII - The follow-up and impact monitoring program; VII - Recommendation of more favorable alternatives (conclusions and comments of general order)" (CONAMA, 2017b).

EIR must have broad publicity and get comments; it is the corollary of popular participation in this environmental sphere (art. 11 of CONAMA Resolution 001/1986).

\subsubsection{Simplified Environmental Study}

The CONAMA Resolution 237/1997, in its Article 12, first paragraph, also sets the possibility of simplified procedures for activities and ventures of small potential environmental impact that must be approved by the respective Environment Councils.

Accordingly, criteria to speed up and simplify the process must be institutionalized. The chosen procedures must implement the voluntary environment management plans and programs, aiming at the continuous improvement and enhancement of the environmental performance ( $\$ 3$ of art. 12).

Still, for procedure simplification purposes, the second paragraph of Article 12 admits "one single environmental licensing process for small ventures and similar and neighbor activities or for those integrating the development plans previously approved by the competent governmental agencies, as long as the legal responsibility is defined by the set of ventures and activities."

Thus, it is worth emphasizing that besides the types of environmental studies listed in the aforementioned topics, the CONAMA Resolution 237/1997 still makes some other specific studies possible, namely: environmental reports, environmental control plans and projects, preliminary environmental reports, environmental diagnosis, handling plans, recovery plan of 
degraded area and preliminary risk analysis.

\section{Carbon Capture and Storage Projects in Brazil}

According to Macedo (2017, p.33), the issue of global climate change has became a problem of global collective action since the 1990s considering the human capacity to interfere in the climate system, because of its scale and reach. For this author, since then, relationship between science and politics has become increasingly complex.

The Intergovernmental Panel on Climate Change (IPCC), established in 1988 by the World Meteorological Organization (WMO), issued a report in 2015 outlining risk aspects of climate change and the urgent need to ensure that the global average temperature the $21 \mathrm{st}$ century does not exceed $2^{\circ} \mathrm{C}$, remaining within a "carbon budget" estimated at 200GtCO2e (IPCC, 2015, MACEDO, 2017).

The carbon budget is an estimate based on the accumulation of greenhouse gases ("GHG") in the atmosphere, stabilized at 450ppm, compatible with a maximum global temperature rise of up to $2^{\circ} \mathrm{C}$. The total would be $2,900 \mathrm{GtCO} 2 \mathrm{e}$, of which $1,900 \mathrm{GtCO} 2 \mathrm{e}$ was already used between 1970 and 2011. (IPCC, 2015, MACEDO, 2017). The Paris Agreement, signed in April 2016 by 175 countries in New York City, entered into force in November of the same year, and establishes a carbon budget distributed among countries to ensure that the global average temperature does not exceed $2^{\circ} \mathrm{C}$ to 2,100. Brazil, a signatory, submitted in 2016, through the Ministry of the Environment, a basic document to define the strategy to implement the country's commitments from 2020, according to the Nationally Determined Contribution (NDC) (MACEDO, 2017).

Although the objective is that the document is "intended to be a nationally determined contribution", the Brazilian text proposes that the industrial sector "promote new standards of clean technologies and increase measures of energy efficiency and low-carbon infrastructure", among other forms of mitigation measures to be implemented by the country, which expects to reduce greenhouse gas emissions by $37 \%$ below 2005 levels by 2025 . According to the IEA (2016), energy generation is currently one of the main sources of carbon emissions in Brazil, accounting for $43.6 \%$ of the $\mathrm{CO} 2$ emitted by stationary sources.

Carbon Capture, Storage and Transport (CCS) has gained prominence for the permanent storage capacity of high volumes of $\mathrm{CO} 2$, in appropriate geological formations (ALMEIDA et al., 2017) as one of the main alternatives for reducing CO2 emissions. The authors point out that the technique consists of injecting compressed $\mathrm{CO} 2$ (in the supercritical state) into rocks, such as sandstones, willows, dolomites, basalts or charcoal. In order to become CO2 reservoirs, in addition to maintaining adequate porosity and permeability, these rocks must present a satisfactory seal and a stable geological environment in order to avoid compromising the integrity of the storage site (Almeida et al., 2017, p. 2.).

For the authors, in the Brazilian scenario, CCS technology may represent a strategic alternative for $\mathrm{CO} 2$ reduction, especially for the energy sector, and, nevertheless, observe that knowledge about this technology is still little consolidated in the country, as well as the respective regulation of this activity (ALMEIDA et al., 2017, p.2). 
The Brazilian National Plan on Climate Change (2008, p. 98-99) mention CCS as a technique of GHG emission mitigation and the Brazilian National Policy for Climate Change include among its aims the GHG reduction and the CO2 capture (Law 12,187/2009, art. 4, II and IV). Also, the São Paulo State Policy for Climate Change points out as an objective the increase of projects of CO2 capture and storage (State Law 13.798/2009, art. 5, II).

According to OCDE/IEA (2016) in 2013, in Brazil, the combustion of oil products was responsible for $70 \%$ of total fossil-fuel-related $\mathrm{CO} 2$ emissions, of which road transport has a share of $40 \%$ in total emissions. Only 17\% of Brazil's CO2 emissions in 2013 stemmed from power generation, due to the large share of hydropower in Brazil's electricity generation (more than 60\% in 2015). The CO2 emissions in Brazil increased, on average, by $3.3 \%$ over the last 10 years, with variations from a $6.6 \%$ decrease in 2009 , to a $13.5 \%$ increase in 2010 and to a decrease of $3.8 \%$ in 2015 . The share in the global total also increased from $1 \%$ in 1990 to $1.3 \%$ in 2015 (Shearer et al., 2016).

Brazil has almost doubled its coal consumption since 1990. Over the last decade, the average increase in coal consumption was 3.6\%, with large annual variations such as a decrease of $19.3 \%$ in 2009 followed by an increase of $30.2 \%$ in 2010. In 2015, coal consumption decreased by $0.8 \%$ (BP, 2016). Since 2010, Brazil has added $1.8 \mathrm{GW}$ in new coal power capacity (Shearer et al., 2016). Despite a negative economic growth rate of $3.8 \%$ in 2015, Brazil is the ninth largest economy in the world. It developed a services sector, which contributes around $68 \%$ to its national GDP, followed by the manufacturing and agricultural sectors with $26 \%$ and $6 \%$, respectively (BP, 2016). In 2015, Brazil also added significant, new renewable capacity (REN21, 2016) and had a share of $9.1 \%$ in total global hydropower consumption (BP, 2016).

As previously noted, the CONAMA Resolution 01/1986 sets forth the Environmental Impact Assessment (EIA) and Environmental Impact Report (EIR) as a condition for the competent environmental regulatory agency granting of an environmental licensing for an activity. The resolution also provides a list of activities subject to environmental licensing compliance in Brazil and the document was the main reference to ROMEIRO-CONTURBIA (2014) to assess if CCS projects should be subject of environmental licensing. According to the author:

(i) For the capture of $\mathrm{CO} 2$, the list includes large stationary source facilities with potential to include $\mathrm{CO} 2$ capture technologies (such as coal-fired power plants, cement and steel plants, oil and gas, oil production platforms etc.);

(ii) For the transport of $\mathrm{CO} 2$, the list includes a category on "transport, terminals and deposits", establishing that all transport of dangerous goods, pipeline transport, marinas, ports and airports, ore terminals, petroleum and chemicals, deposit of chemicals and hazardous products are required to comply with environmental licensing processes.

(iii) For the storage of $\mathrm{CO} 2$, the list includes a category on "extraction and mineral treatment" with a sub topic on well drillings and oil and gas production.

Even if the CCS activities are not considered to be included in those list, Article 2 of Resolution $237 / 97$ of CONAMA states that it is the responsibility of the competent 
environmental regulator to define the criteria and details of compliance to be complimented by the list, considering the specifics, environmental risks, size and other characteristics of the enterprise or activity. As discussed, the scope of the CONAMA's list should be broad enough to include practically all the productive sectors. For Romeiro-Conturbia (2014), it can be said that the national environmental law in Brazil is broad enough to require all the activities in a CCS project to comply with complete environmental licensing procedures.

As seen previously, the CONAMA Resolution 237/1997 states that the "design, construction, installation, expansion, modification and operation" of any enterprise or activity that uses environmental resources and that can be effectively or potentially pollutant is subject to environmental licensing by the competent environmental regulatory agency.

For CO2 Capture and Separation must consider that capture can be carried out through four main processes: post-combustion, pre-combustion, oxy-combustion and industrial processes separation (IPCC, 2015). Hence, in the words of Romeiro-Conturbia (2014), for the capture of $\mathrm{CO} 2$, it can be assumed that a facility that has been already licensed (a coal-fired power plant in operation, for example), would need to request approval of the competent environmental regulatory agency to include a $\mathrm{CO} 2$ capture activity as part of the environmental licensing. The author remarks that the exception would be in cases where the environmental licensing of a facility anticipates the inclusion of $\mathrm{CO} 2$ technologies, as the case of the Pre-Sal Lula Oil Field environmental licensing that already includes the capture, transport and storage of CCS as part of its activities (ROMEIRO-CONTURBIA, 2014).

Captured $\mathrm{CO} 2$ must be transported from the emitting source to the storage site. The pipeline system, similar to those used to transport natural gas, is $\mathrm{CO} 2$ transport option. Other options include trucking and shipping. Usually $\mathrm{CO} 2$ is compressed to a supercritical state (or a 'dense phase') for transport and injection (KETZER, et. al, 2014). Depending on how long the pipeline is, the $\mathrm{CO} 2$ may need to be 'recompressed' along various points of the pipeline to keep it in this 'dense phase'. (KETZER, et. al, 2014).

For the transport of CO2, the Romeiro-Conturbia (2014) says that either the installation of a $\mathrm{CO} 2$ pipeline and the modification of gas pipelines to $\mathrm{CO} 2$ pipelines would be subject of approval by the competent environmental regulatory agency.

For CO2 Geological Storage, the main geological options than can safely store large amounts of $\mathrm{CO} 2$ and keep it from reaching the atmosphere are oil and gas fields and deep saline formations (KETZER, et. al, 2014). According to the authors, in most cases, and due to the increase in temperature and pressure with depth, injected $\mathrm{CO} 2$ will be in a supercritical (or dense phase) state (pressure $>7.38$ megapascal $(\mathrm{MPa})$ and temperature $>31.1^{\circ} \mathrm{C}$ ). The same authors say that in this condition, $\mathrm{CO} 2$ acquires a liquid-like density, between 600 and 800 kilogram per cubic meter $(\mathrm{kg} / \mathrm{m} 3)$ therefore occupying a smaller pore volume, leading to more efficient storage, and that to ensure storage in a supercritical state, the minimum depth estimated for a reservoir is around 800 meters (m) (KETZER, et. al, 2014).

And, for the storage of $\mathrm{CO} 2$, either the drilling of new wells or the modification of oil wells to store $\mathrm{CO} 2$ would be subject of approval by the competent environmental regulatory agency 
(ROMEIRO-CONTURBIA, 2014).

The result of the research involving an IBAMA interlocutor by Romeiro-Conturbia (2014) clarified that, in practice, modifications in a current licensed activity or undertaking are relatively common over time, and depending on the size of the modification, environmental competence regulatory agency can only request a letter of consent. This may be the case for an offshore oil production platform, for example, an operator may decide to drill an additional well that was not expected and included in the corresponding environmental licensing. The interlocutor points out that other activities with greater impact, such as the expansion or establishment of a new platform in an already licensed area, it is likely that a new license or new installation license is required, depending on the case.

In any case, any change in a licensed installation must be reported to the relevant environmental regulator to verify the need for a new license or not. Another important point is that having an only and integrated environmental licensing for all activities of a CCS project has the advantages of reducing bureaucracy and delays in the process, as well as allowing the regulator to have an integrated perception of the entire project. However, Romeiro-Conturbia (2014) points out that a unified approach could result in greater complexity, especially in CCS projects involving multiple firms, or in projects whose baseline information for each activity (capture, transport and storage) may not be fully available in the time required to start activities.

\subsection{IBAMA Normative Instruction 12/2010}

An important milestone for the institutionalization of CCS activities in Brazil is the IBAMA Normative Instruction 12/2010, which in its article 2 determines that the Licensing Board of IBAMA evaluate, in the licensing process of activities capable of emitting gases of effect greenhouse, the measures proposed by the entrepreneur with the objective of mitigating these environmental impacts, in compliance with the commitments assumed by Brazil in the United Nations Framework Convention on Climate Change.

In other words, the assessment of proposed mitigation measures became part of the merits of the activity licensing process. For this purpose, article 3 of the Normative Instruction determined by the Terms of Reference, prepared by IBAMA, should guide the Environmental Impact Studies for the licensing of projects capable of emitting greenhouse gases, contemplate measures to mitigate or compensate for these environmental impacts in line with the National Plan on Climate Change. In this way, there is support in the regulation of the regulatory body itself, so that activities to mitigate $\mathrm{CO} 2$ emission should be requirements for obtaining licenses.

\section{EIA and MMA Ordinance 422/2011: Experience from Natural Oil\&Gas Projects}

The Ministry of Environment issued the Ordinance 422/2011 (Brasil, 2017f) that provides for procedures for federal environmental licensing of activities and projects of exploration and production of oil and natural gas in the marine environment (offshore) and onshore in the land-sea transition zone. 
The Ordinance divided the environmental licensing procedure according to the stage of the project: (i) seismic research; (ii) exploration well drilling; and (iii) production, draining of oil and natural gas and long test duration (TLD).

According to the stage of the project and to its technical aspects, the environmental assessment differ, as follows:

(i) seismic research: (A) Class 1 - Seismic research in depth less than 50 meters or in areas of environmental sensitivity - Environmental Impact Assessment / Report (EIA/RIMA); (B) Class 2 - Deep seismic surveys between 50 and 200 meters - Environmental Study of Seismic / Environmental Impact Report of Seismic - EAS / RIAS; (C) Class 3 - Seismic surveys in depth greater than 200 meters, being required the elaboration of Environmental Study of Seismic-EAS or Complementary Information to the Control Plan of Earthquake (Article 4, II);

(ii) exploration well drilling: (A) Class 1 - Deep sea drilling less than 50 meters or less than 50 kilometers away coastal areas or in areas of environmental sensitivity, requiring - Environmental Impact Assessment / Report (EIA/RIMA); (B) Class 2 - Deep sea drilling between 50 and 1000 meters, more than 50 kilometers away of the coast, equiring the elaboration of Environmental Drilling / Reporting of Environmental Impact of Drilling - EAP / RIAP; (C) Class 3 - Deep sea drilling More than 1000 meters, more than 50 kilometers away of the coast, requiring the elaboration of an Environmental Drilling Study (Article 9, II);

(iii) production: Environmental Impact Assessment / Report (EIA/RIMA), Article 14, II.

As the activities are previous to the production and located far from the coastal area and from environmental sensitive areas, as islands and coral reefs, the assessments required are simpler. Also, the seismic research and exploration activities only require one environmental license (LO).

Article 13 of this standard says that the establishment or expansion of maritime ventures for the production and disposal of oil and natural gas depends on obtaining the following licenses from IBAMA: I - Previous License-LP: II - Installation License-LI: III - Operation License-LO, no novelty in relation to cases that require EIA.

However, paragraph 1 of the same article says that in the case of projects consisting of different projects or involving different activities, more than one Installation or Operation License may be issued, following a single Previous License, according to the implementation schedule characteristics of the enterprise. This can be understood as an opening for the implementation of licenses for CCS activities in petroleum and natural gas projects that already have a previous license.

Paragraph 2 of the article 13 states that in the case of projects that do not include installation activities, the Operating License may be granted directly, which, if analyzed more boldly, may be the case of the use of wells already installed for storage of $\mathrm{CO} 2$. In order to complete 
the reasoning, and on the basis of $\S 3$ of the same article, the oil and natural gas production and disposal enterprise may include drilling activities within its scope, for which a specific LO Operation License shall be issued.

Other important determinations of the cited norm are in articles 26 and 27, which provide that modifications to the project that do not imply important changes may be authorized by IBAMA in an existing licensing procedure. In this way, says art. 26 that a project modification that does not imply a relevant alteration of the environmental impact assessment carried out as a subsidy for the granting of the environmental license may be authorized by IBAMA in the same environmental licensing procedure, based on a specific act. It is important to note what the article requires for this request: Paragraph 1 The request for modification referred to in the main section of this article must be accompanied by the following information: I - degree of alteration of the impact assessment carried out due to the project modification; and II - justification for the modification of the project after the granting of the environmental license.

In another paragraph (2) of this article 26 , there is provision for cases that imply a relevant change, of which IBAMA will require a new licensing procedure, without prejudice to the use of the acts already performed and the documents previously produced.

Article 27, expressly establishes prior environmental licensing (for the construction, installation, expansion and operation of establishments and activities that use environmental resources, effectively or potentially polluting or capable of, in any way, cause environmental degradation will depend on prior environmental licensing), and set forth that IBAMA will be responsible for the licensing requirement for other oil exploration and production activities not contemplated in Ordinance 422, stating that it will request from the entrepreneur the necessary subsidies for the evaluation of the characteristics of the enterprise, its impacts and the environmental risks involved.

The sole paragraph of article 27 concludes that based on the characteristics of the enterprise and the environmental sensitivity of the region where it will be located, IBAMA will define the specific procedures pertinent to environmental licensing. Thus, it is abstracted from the norm in defining "other maritime activities of exploration and production of oil" and, if considered as an inherent activity of this type of production, $\mathrm{CO} 2$ storage can be interpreted in this context.

Another important provision of the Ordinance is the possibility that IBAMA considers environmental assessments carried out for other projects as those of regional scope, Environmental Studies of Sedimentary Area (EAAS) and respective Concluding Reports, consolidated after Public Consultation and validated by the competent body by specific act in processes of Environmental Assessments of Sedimentary Area (AAAS), and studies carried out under responsibility, demand or supervision of the federal public power, including those coming from other environmental licensing processes, at the discretion of IBAMA.

Moreover, frequently, the Public Attorney initiates its own administrative proceedings ("Inquéritos Civis") to monitor the progress of the environmental permitting procedures. If it 
finds any illegality or inconsistency in the environmental studies and the procedure, it may file a civil action seeking the regularization of the procedure and the remediation/indemnification of environmental damages, based on the joint, strict and several liability doctrine.

It should be stressed that the Not Government Organizations (NGOs) also have the power to file civil actions for the same purpose, which has been occurring more often. Therefore, though the environmental agency has the authority to conduct the permitting procedure, the society has strong legal instruments that allow it to effectively participate in this procedure.

\section{Conclusion}

This article intended to describe the environmental licensing system in Brazil and its special instrument, the environmental impact assessment (EIA), as well as describes the specific aspects on CCS projects.

Because of that, this research started the description of the National Environmental Policy Act enacted by Law 6,938/1981, that established the main formulation and application mechanisms of the environmental policy, among them, "assessing environmental impacts" and "licensing and revising the effective or potentially polluting activities". In this line, Brazilian Environmental Council made published Resolution 237/1997 and defined the environmental licensing tools.

As this research has shown, the environmental permitting procedure of oil and gas activities begin with the development of an Environmental Impact Assessment and its related report ("EIA/RIMA"), which must be submitted to the environmental agency with the application for the environmental licenses. Specifically, for the environmental licensing of exploration and production of oil, natural gas and other fluid hydrocarbons (mainly unconventional activities), in 2015, Federal Decree 8,437 established the IBAMA's competence and the MMA Ordinance 422/2011 provides for specific stages and tools for offshore activities.

Moreover, this article has highlighted that on licenses for onshore activities, these are generally granted by the state environmental agency and for offshore activities, usually by the federal agency, IBAMA. In cases involving activities which may cause significant national or regional environmental impacts, IBAMA has the authority to issue the permits.

Despite those basic rules, in practice, conflicts of interests between state and federal agencies may be raised. For instance, activities that affect coastal zones may not be significant and of national or regional proportions, however, IBAMA has argued its competence due to coastal zones belonged to Federal Government.

Therefore, results on the legislation analysis have shown that Brazil has made progress in defining environmental licenses and EIAs' attributes in oil and natural gas projects. However, conflicts may be urged during environmental processes because of the diversity of public competences among Federal Union, states and municipalities. This paper recommends in those cases that the focus will be a balance between private interests and environmental protection. 
Despite the lack of regulation of CCS activities in Brazil, the use of such technique for CO2 emissions mitigation or reduction is aligned with the National Policy for Climate Change objectives. Thus, it is important to evaluate how the environmental licensing procedure could contribute to the development of such activity granting environmental protection. As seen, according to the applicable law, CCS activities must be subject to environmental licensing procedure, including a complete EIA/RIMA. The environmental impact assessment of CCS activities may be a part of a border assessment for multiple activities. Nevertheless, the specific impacts of CCS activities should be evaluated and approved by the competent environmental agency.

\section{Acknowledgement}

The authors gratefully acknowledge support from BG E\&P Brasil, a subsidiary of Royal Dutch Shell, and FAPESP through the "Reserch Centre for Gas Innovation - RCGI" (Fapesp Proc. 2014/50279-4), hosted by the University of Sao Paulo, and the strategic importance of the support given by ANP (Brazil's National Oil, Natural Gas and Biofuels Agency) through the R\&D levy regulation, as well as the University of São Paulo, CAPES and the Program of Human Resources n.04.

\section{References}

Almeida, J. R. L., Rocha, H. V., \& Costa, H. K. M. (2017). MOUTINHO dos Santos, E. The Analysis of Civil Liability Regarding CCS: Brazilian Case. In: 6th Latin American Energy Economics Meeting, 2017, Rio De Janeiro. Anais do 6th Latin American Energy Economics Meeting. Rio De Janeiro: Instituto De Economia da UFRJ, 6, 1-10.

BP. (2016). 2030 Energy Outlook. BP Statistical Review of World Energy 2016. Internet:http://www.bp.com/en/global/corporate/energy-economics/statistical-review-of-worl d- energy.html

Brasil. Constituição Federal da República do Brasil. (2017a). http://www.planalto.gov.br/ccivil_03/constituicao/constituicaocompilado.htm.

Brasil. Plano Nacional sobre Mudança do Clima - PNMC, 2008. Decreto $\mathrm{n}^{\circ} 6.263$ de 21/11/2007

http://www.mma.gov.br/estruturas/smcq_climaticas/_arquivos/plano_nacional_mudanca_cli ma.pdf

Brasil. Presidência da República do Brasil. (2017b). Lei da PNMA. Https://www.planalto.gov.br/ccivil_03/leis/16938.htm.

Brasil. Presidência da República do Brasil. (2017c). Lei Complementar 140/2011. http://www.planalto.gov.br/ccivil_03/leis/lcp/lcp140.htm.

Brasil. Presidência da República do Brasil. (2017d). Lei 13.123, de 20 de maio de 2015. Http://www.planalto.gov.br/ccivil_03/_ato2015-2018/2015/lei/113123.htm.

Brasil. Presidência da República do Brasil. (2017e). Federal Decree 8,437/2015. Http://www.planalto.gov.br/ccivil_03/_ato2015-2018/2015/decreto/d8437.htm 


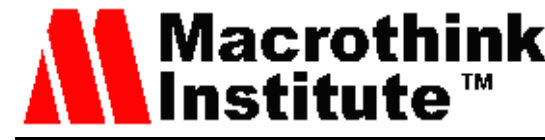

Journal of Public Administration and Governance

ISSN 2161-7104 2018, Vol. 8, No. 3

Brasil. Presidência da República do Brasil. (2017f). Ordinance 422/2011. Http://licenciamento.ibama.gov.br/encontro\%20superintendentes\%20-\%20dilic/normativos/p ortaria_mma_422\%20-\%20licenciamento\%20petroleo\%20e\%20gas $\% 20$ exploracao.pdf

Cavalcante, A. B., Costa, H. K. M., \& Freitas, 1. R. (2005) Lei de crimes ambientais: aplicações e reflexos atinentes à indústria do petróleo e gás. In: yanko marcius xavier; nizomar. (org.). Direito ambiental aplicado à indústria de petróleo e gás natural. 1ed.fortaleza: Konrad Adenauer, p. 87-130.

Conama. $\quad$ Resolução $\quad 237, \quad$ de 1997.

(2017a).

Http://www.mma.gov.br/port/conama/res/res97/res23797.html.

Conama. Resolução conama 001/1986. (2017a). Www.ibama.gov.br.

Costa, H. K. M. (2017). O princípio da justiça intra e intergeracional como elemento na destinação das rendas de hidrocarbonetos temática energética crítica na análise institucional brasileira. 342f. Tese ( doutorado em ciências)- programa de pós-graduação em energia da universidade de são paulo, são paulo, 2012. Costa, h. K. M., et al. Capitulo 17. In: Energias Renováveis, Geração Distribuída e Eficiência Energética. Ltc Editorial - Grupo Gen: Rio de Janeiro.

Estocolmo.http://www.direitoshumanos.usp.br/index.php/meio-ambiente/declaracao-de-estoc olmo-sobre-oambiente-humano.html

Goldemberg, J., \& Villanueva, L. D. (2003) Energia, Meio Ambiente \& Desenvolvimento. 2. Ed. Tradução: André Koch. São Paulo: Editora da Universidade de São Paulo.

Ibama - Instituto Brasileiro do Meio Ambiente e dos Recursos Naturais Renováveis (2017a). Histórico. Http://www.ibama.gov.br/acesso-a-informacao/historico. Access in: apr. 2017.

Ibama - Instituto Brasileiro do Meio Ambiente e dos Recursos Naturais Renováveis. (2017b). Identidade

organizacional: http://www.ibama.gov.br/acesso-a-informacao/identidadeorganizacional. Access in: apr. 2017.

Ibama - Instituto Brasileiro do Meio Ambiente e dos Recursos Naturais Renováveis. Instrução normativa n. 10, de 7 de dezembro de 2012. Regula os procedimentos para apuração de infrações administrativas por condutas e atividades lesivas ao meio ambiente, a imposição das sanções, a defesa, o sistema recursal e a cobrança de multas no âmbito do ibama: http://www.ibama.gov.br/sophia/cnia/legislacao/ibama/in0010-071212.pdf. Access in apr. 2018.

IEA. (2016). Decoupling of global emissions and economic growth confirmed. 16 March 2016. International Energy Agency, Paris Internet: https://www.iea.org/newsroom/news/2016/march/decoupling-of-globalemissions-andeconomic-growth-confirmed.html

IPCC, Intergovernmental Panel on Climate Change. Renewable Energy Sources and Climate Change Mitigation. 2015. 
Ketzer, J. M. M., Machado, C. X., Rockett, G. C., \& Iglesias, R. S. (2014). Brazilian Atlas of CO2 Capture and Geological Storage [recurso eletrônico] - dados eletrônicos. - Porto Alegre EDIPUCRS.

66

Https://hub.globalccsinstitute.com/sites/default/files/publications/190903/brazilian-atlas-co2capture-geological-storage.pdf

Macedo, L. S. V. (2017). Participação de Cidades Brasileiras na Governança Multinível das Mudanças Climáticas. Tese (doutorado Em Ciência Ambiental) Programa de Pós-Graduação em Ciência Ambiental -Instituto de Energia d Ambiente da Universidade de São Paulo. São Paulo, p. 248.

Machado, P. A. L. (2009). Direito Ambiental Brasileiro. 17 ed. São Paulo: Malheiros. Marchesan, Ana Maria Moreira; Steigleder, Annelise Monteiro; Cappelli,

Milaré, E. (2009) Direito do Ambiente: A Gestão Ambiental em Foco: doutrina, jurisprudência, glossário. 6 ed. São Paulo: Editora Revista dos Tribunais.

Ministério de Meio Ambiente (MMA). (1992) Declaração do Rio. http://www.mma.gov.br/port/sdi/ea/documentos/convs/decl_rio92.pdf.

Ministério do Meio Ambiente (MMA) (2011) Portaria MMA $n^{\circ} 441$ de 11/11/2011. Aprova as normas e procedimentos a serem observados nos processos de seleção de consultoria de pessoa física, no âmbito deste ministério. Norma Federal. Publicado no DO em 14 nov 2011.

Moraes, A. (2010). Direito Constitucional. 26 ed. São Paulo: Atlas.

Oliveira, C. A., Grimoni, J. A. B., Silva, F. A. T., \& Udaeta, M. E. M. (2004). A Evolução da Importância Ambiental. In: Iniciação a Conceitos de Sistemas Energéticos para o Desenvolvimento Limpo. São Paulo: Editora Da Universidade De São Paulo, p. 39-65.

Romeiro-Conturbia, V. R. D. S. (2014) Carbon Capture and Storage Legal and Regulatory Framework in Developing Countries: proposals for Brazil. (2014). Phd Dissertation. Institute of Environment and Energy. University of Sao Paulo, p. 139-153.

Sao, P. (2009). Sao Paulo State Policy on Climate Change. State Law no13.798 of 2009.

Shearer, C., Ghio, N., Myllyvirta, L., \& Nace, T. (2016). Boom and Bust: tracking the global coal plant pipeline, coalswarm, Sierra Club, San Francisco, California.

Sílvia. (2010). Direito Ambiental. 1.ed. Porto Alegre: Verbo Jurídico.

Universidade de São Paulo (USP), Biblioteca de Direitos Humanos da. (1972). Declaração de

\section{Copyright Disclaimer}

Copyright for this article is retained by the author(s), with first publication rights granted to the journal.

This is an open-access article distributed under the terms and conditions of the Creative Commons Attribution license (http://creativecommons.org/licenses/by/4.0/). 